\title{
Migraine Mutations Impair Hippocampal Learning Despite Enhanced Long-Term Potentiation
}

\author{
Ergin Dilekoz, ${ }^{1 \star}$ Thijs Houben, ${ }^{1,2 \star}$ Katharina Eikermann-Haerter, ${ }^{1}$ Mustafa Balkaya, ${ }^{1}$ A. Mariette Lenselink, ${ }^{4}$ \\ Michael J. Whalen, ${ }^{5}$ Sabine Spijker, ${ }^{4}$ Michel D. Ferrari, ${ }^{2}$ Arn M.J.M. van den Maagdenberg, ${ }^{2,3}$ and Cenk Ayata ${ }^{1,6}$ \\ ${ }^{1}$ Neurovascular Research Laboratory, Department of Radiology, Massachusetts General Hospital, Harvard Medical School, Charlestown, Massachusetts \\ 02129, Departments of ${ }^{2}$ Neurology and ${ }^{3}$ Human Genetics, Leiden University Medical Center, 2300 RC Leiden, The Netherlands, ${ }^{4}$ Department of Molecular \\ and Cellular Neurobiology, Center for Neurogenomics and Cognitive Research, Neuroscience Campus Amsterdam, VU University, 1081 HV Amsterdam, \\ The Netherlands, ${ }^{5}$ Department of Pediatric Critical Care Medicine and ${ }^{6}$ Stroke Service and Neuroscience Intensive Care Unit, Department of Neurology, \\ Massachusetts General Hospital, Harvard Medical School, Boston, Massachusetts 02114
}

To explain cognitive and memory difficulties observed in some familial hemiplegic migraine (FHM) patients, we examined hippocampal neurotransmission and plasticity in knock-in mice expressing the FHM type 1 (FHM1) R192Q gain-of function mutation in the CACNA1A gene that encodes the $\alpha_{1 \mathrm{~A}}$ subunit of neuronal $\mathrm{Ca}_{\mathrm{V}} 2.1$ channels. We determined stimulus intensity-response curves for anterior commissure-evoked hippocampal CA1 field potentials in strata pyramidale and radiatum and assessed neuroplasticity by inducing long-term potentiation (LTP) and long-term depression (LTD) in anesthetized mice in vivo. We also studied learning and memory using contextual fear-conditioning, Morris water maze, and novel object recognition tests. Hippocampal field potentials were significantly enhanced in R192Q mice compared with wild-type controls. Stimulus intensity-response curves were shifted to the left and displayed larger maxima in the mutants. LTP was augmented by twofold in R192Q mice, whereas LTD was unchanged compared with wild-type mice. R192Q mice showed significant spatial memory deficits in contextual fear-conditioning and Morris water maze tests compared with wild-type controls. Novel object recognition was not impaired in R192Q mice; however, mice carrying the more severe S218L CACNA1A mutation showed marked deficits in this test, suggesting a genotype-phenotype relationship. Thus, whereas FHM1 gain-of-function mutations enhance hippocampal excitatory transmission and LTP, learning and memory are paradoxically impaired, providing a possible explanation for cognitive changes detected in FHM. Data suggest that abnormally enhanced plasticity can be as detrimental to efficient learning as reduced plasticity and highlight how genetically enhanced neuronal excitability may impact cognitive function.

Key words: hippocampus; learning; long-term depression; long-term potentiation; memory; migraine

\section{Introduction}

Familial hemiplegic migraine (FHM) is a monogenic form of migraine with aura, characterized by transient hemiplegia during the aura phase (Headache Classification Subcommittee of the International Headache Society, 2004). FHM type 1 (FHM1) is caused by mutations in the CACNA1A gene that encodes the pore-forming $\alpha_{1 \mathrm{~A}}$ subunit of $\mathrm{Ca}_{\mathrm{V}} 2.1$ (P/Q-type) calcium chan-

Received June 27, 2014; revised Dec. 29, 2014; accepted Jan. 1, 2015.

Author contributions: E.D., S.S., M.D.F., A.M.J.M.v.d.M., and C.A. designed research; E.D., T.H., K.E.-H., M.B., and M.L. performed research; E.D., T.H., K.E.-H., M.B., M.L., M.J.W., and S.S. analyzed data; T.H., M.J.W., M.D.F., A.M.J.M.v.d.M., and C.A. wrote the paper.

This work was supported by National Institutes of Health Grant NS061505, Fondation Leducq, the Neuroendovascular Research Fund from the Andrew David Heitman Foundation, the Ellison Foundation, the Netherlands Consortium for Systems Biology/Center for Medical Systems Biology in the framework of the Netherlands Genomics Initiative, the European Union nr 602633 EUROHEADPAIN, and the International Headache Society 2012 Fellowship Award.

*E.D. and T.H. contributed equally to this work.

The authors declare no competing financial interests.

Correspondence should be addressed to Dr. Cenk Ayata, Neurovascular Research Laboratory, Massachusetts General Hospital, 149 13th Street, Room 6408, Charlestown, MA 02129. E-mail: cayata@partners.org.

E. Dilekoz's present address: Department of Pharmacology, Gazi University Faculty of Medicine, Besevler, Ankara, Turkey 06500

DOI:10.1523/JNEUROSCI.2630-14.2015

Copyright $\odot 2015$ the authors $\quad 0270-6474 / 15 / 353397-06 \$ 15.00 / 0$ nels (Ophoff et al., 1996; Pietrobon and Moskowitz, 2013). Functionally, FHM1 mutations increase $\mathrm{Ca}_{\mathrm{v}} 2$.1-dependent neuronal $\mathrm{Ca}^{2+}$ influx and cortical glutamatergic neurotransmission (Tottene et al., 2002, 2009; van den Maagdenberg et al., 2004, 2010). As a result, FHM1 transgenic mice display enhanced cortical and subcortical spreading depression susceptibility (van den Maagdenberg et al., 2004, 2010; Tottene et al., 2009; Eikermann-Haerter et al., 2011). Cognitive and memory difficulties have been reported in several families with FHM (Kors et al., 2003; Karner et al., 2010, 2012; Freilinger et al., 2011) and in small and large cohorts of more common forms of migraine with or without aura (Le Pira et al., 2000; Calandre et al., 2002; Kalaydjian et al., 2007), although not all studies agree on the latter (Suhr and Seng, 2012). As one example, standardized neuropsychological tests in a family with six FHM1 patients have shown that although verbal intelligence, verbal memory, and mental arithmetic capacity were normal compared with population averages, specific recall of complex spatial visual cues was markedly impaired (Karner et al., 2010, 2012). Because the latter critically depends on hippocampal, glutamate-mediated neuronal plasticity (Lu et al., 1997; Bohbot et al., 1998; Wang et al., 2009), we examined whether such learning deficits are also present in FHM1 transgenic mice and, if 
so, whether these traits are linked to impaired hippocampal plasticity.

\section{Materials and Methods}

Experimental groups. All experiments were performed in accordance with the U.S. Public Health Service Policy on Humane Care and Use of Laboratory Animals and were approved by the Massachusetts General Hospital Subcommittee on Research Animal Care or the animal research committee of the VU University Amsterdam. Female and male FHM1 knock-in mice homozygous for the R192Q mutation or heterozygous or homozygous for the S218L missense mutation (van den Maagdenberg et al., 2004, 2010) in the CACNA1A gene were compared with wild-type (WT) littermates. Before all experiments, mice were allowed to acclimate for at least $3 \mathrm{~d}$ to controlled housing conditions (lights on/off at 7:00 A.M./7:00 P.M.). Before fear-conditioning training, male mice (9-10 weeks) were individually housed with cage enrichment (nesting material and a PVC tube). In all other tests, female mice of 10-16 weeks were used. All investigators were blinded to the genotype of the mice during data collection and analysis.

General surgical procedures. For the electrophysiological experiments, mice were anesthetized ( $3 \%$ isoflurane in $70 \% \mathrm{~N}_{2} \mathrm{O} / 30 \% \mathrm{O}_{2}$ for induction, $1.5 \%$ isoflurane in $70 \% \mathrm{~N}_{2} \mathrm{O} / 30 \% \mathrm{O}_{2}$ for surgical procedures, and $1.5 \%$ isoflurane in $75 \% \mathrm{~N}_{2} / 25 \% \mathrm{O}_{2}$ for field potential recordings), and femoral arteries were catheterized for arterial pressure and blood gas measurements. Mean arterial pressure, $\mathrm{pH}, \mathrm{pCO}_{2}$, and $\mathrm{pO}_{2}$ did not differ between WT and FHM1 mutant mice ( $73 \pm 1$ and $72 \pm 1 \mathrm{mmHg}, 7.34 \pm$ 0.01 and $7.32 \pm 0.01,38 \pm 1$ and $41 \pm 1 \mathrm{mmHg}, 115 \pm 6$ and $115 \pm 3$ $\mathrm{mmHg}$, respectively). Mice were then placed in a stereotaxic frame ( $\mathrm{Da}-$ vid Kopf Instruments). Rectal temperature was maintained at $37^{\circ} \mathrm{C}$ (FHC). Under saline cooling, two cranial windows (1 $\mathrm{mm}$ diameter) were drilled over the right hemisphere at the following coordinates from bregma: (1) $0.5 \mathrm{~mm}$ anterior and $0.5 \mathrm{~mm}$ lateral for stimulation electrode and (2) $1.8 \mathrm{~mm}$ posterior and $1.5 \mathrm{~mm}$ lateral for recording electrode. The dura was kept intact to minimize trauma.

Hippocampal field potential recordings. A glass micropipette filled with $150 \mathrm{~mm} \mathrm{NaCl}$ was lowered into the stratum pyramidale $(1200 \mu \mathrm{m}$ below dura) using a hydraulic micromanipulator (MO-10; Narishige). Extracellular potentials were recorded using a differential amplifier (EX-1; Dagan) relative to an $\mathrm{Ag} / \mathrm{AgCl}$ reference electrode placed subcutaneously in the neck and stored using a data acquisition system for off-line analysis (PowerLab 200; ADInstruments). A bipolar stimulation electrode was gradually advanced at the frontal cranial window at a $45^{\circ}$ angle in the sagittal plane. Just before reaching the depth of the anterior hippocampal commissure, electrical stimulation was started at $0.1 \mathrm{~Hz}$, using $100 \mu \mathrm{A}$, $100 \mu$ s square pulses (A395 Stimulus Isolator; WPI). The stimulation electrode was then advanced in small increments until reproducible evoked responses became apparent, and the positions of recording and stimulation electrodes were optimized to obtain maximal local field potentials. After determining the threshold stimulation current required to evoke a pyramidal population spike $(63 \pm 10$ and $97 \pm 23 \mu \mathrm{A}$ in WT and $\mathrm{R} 192 \mathrm{Q}$, respectively; $p=0.22$ ), stimulus intensity-response curves for spike amplitude were obtained by increasing the stimulation current in steps of $0.1 \times$ spike threshold until $1.6 \times$ spike threshold value was reached and then in steps of $0.2 \times$ spike threshold until the maximum spike amplitude was obtained. Next, the recording electrode was lowered into the stratum radiatum, and stimulus intensity-response curves for field EPSP (fEPSP) slopes were obtained by increasing the stimulation current starting from $0.1 \times$ spike threshold in steps of 0.3 -fold increments until $1.0 \times$ spike threshold value was reached, and then in steps of 0.4-fold increments until the maximum fEPSP slope was reached.

Long-term potentiation. Stimulation intensity was set to $50 \%$ of the maximal fEPSP slope in each animal. Baseline responses were recorded for $8 \mathrm{~min}(0.1 \mathrm{~Hz}, 100 \mu$ s pulse duration), and three high-frequency stimulus trains $(1 \mathrm{~s}, 100 \mathrm{~Hz}, 20 \mathrm{~s}$ intertrain interval) were applied at test stimulation intensity. Responses were monitored for another $80 \mathrm{~min}$. We could not test long-term potentiation (LTP) in the S218L mutant mice because any conditioning stimulus triggered a spreading depression in this highly susceptible strain.
Long-term depression. In a separate group of mice, stimulation intensity was set to $60 \%$ of the maximal fEPSP slope. Baseline responses were recorded for $20 \mathrm{~min}$, after which 900 paired pulses ( $37 \mu$ s paired-pulse interval, $0.85 \mathrm{~Hz}$ ) were applied. Responses were monitored for another $50 \mathrm{~min}$

Behavioral tests. Before testing, mice were handled to habituate to the experimenter. The day of the test, mice were carried to the behavioral room and testing started immediately (fear conditioning) or they were allowed to acclimate for $1 \mathrm{~h}$ before the experiments. Behavioral experiments were performed between 8:00 A.M. and 8:00 P.M. The more severe neurological phenotype of the S218L mutants, including cerebellar ataxia and an increased susceptibility to seizures (van den Maagdenberg et al., 2010), precluded reliable water maze and fear-conditioning testing; therefore, only novel object recognition was tested in this strain.

Fear conditioning. Contextual training and retrieval were performed in a fear-conditioning system (TSE-Systems) as described previously (RaoRuiz et al., 2011). In brief, mice were placed in an acrylic glass chamber with a stainless steel grid floor for a period of $180 \mathrm{~s}$, subjected to a $2 \mathrm{~s}$ footshock $(0.7 \mathrm{~mA})$, and returned to their home cage 30 s later. Contextual memory retrieval on the second day consisted of re-exposure (3 $\mathrm{min}$ ) to the context. Shock response [maximum velocity $\left(V_{\max }\right)$ ] and freezing were assessed automatically. Freezing was defined as lack of any movement besides respiration and heart beat during $2 \mathrm{~s}$ intervals, presented as a percentage of the total test time. Mice that displayed baseline freezing $>20 \%$ were considered outliers and were removed from the analysis $(n=1)$.

Morris water maze. Highly visible cues were located on the walls of each of the four quadrants in a circular water pool $(83 \mathrm{~cm}$ diameter, $60 \mathrm{~cm}$ deep, $\left.21-25^{\circ} \mathrm{C}\right)$. A clear Plexiglas goal platform $(10 \mathrm{~cm}$ diameter $)$ was positioned $0.5 \mathrm{~cm}$ below the water surface and $15 \mathrm{~cm}$ from the southwest wall. Testing consisted of three periods: hidden platform training, visible platform test, and probe trial. During hidden platform training, mice were placed in the pool facing the pool wall at four starting positions (north, south, east, and west), in randomized order. Mice were given a maximum of $60 \mathrm{~s}$ to find the platform. If the mouse failed to reach the platform, it was placed on the platform for $10 \mathrm{~s}$. The average latency to the goal platform was recorded as the latency for that trial. Animals were trained in this way for five sessions once per day for $5 \mathrm{~d}$. To control for possible differences in visual acuity or sensorimotor function between groups, two subsequent trials were performed on day 4 , using a visible platform raised $0.5 \mathrm{~cm}$ above the surface of the water. One day later, a probe trial was performed in which the mouse was given $60 \mathrm{~s}$ to swim in the pool with the goal platform removed. The time spent in the target quadrant (probe time) was recorded for each mouse.

Novel object recognition. During the first session, mice were placed in a rectangular cage $(35 \times 20 \mathrm{~cm})$ and exposed to two identical objects for 5 min. Mice were then allowed to rest in their home cages for $1 \mathrm{~h}$, followed by a second session during which mice were exposed to a familiar object from the previous session and a novel object for $5 \mathrm{~min}$. The discrimination index was calculated as the ratio between the time spent exploring familiar and novel objects during the second session. Because the R192Q and S218L strains share essentially the same genetic background, they were compared with a single pooled WT group.

Statistics. Data were statistically tested using the $t$ test, Mann-Whitney $U$ test, Kruskal-Wallis test, or two-way ANOVA for repeated measures where appropriate (GraphPad Prism 6.0; GraphPad Software); $p<0.05$ was considered statistically significant.

\section{Results}

\section{Electrophysiology}

Stimulation of the anterior commissure evoked characteristic CA1 field potentials comprising a population spike and wave in stratum pyramidale and a dendritic fEPSP in stratum radiatum in both groups (Fig. 1). Stimulus-response curves for population spike amplitudes showed a significant left shift in homozygous R192Q mice compared with WT mice. Maximal spike amplitudes were also larger in the mutants (Fig. 1C). Stimulus-response curves for fEPSP slopes in the stratum radiatum tended to be 
A Stratum pyramidale

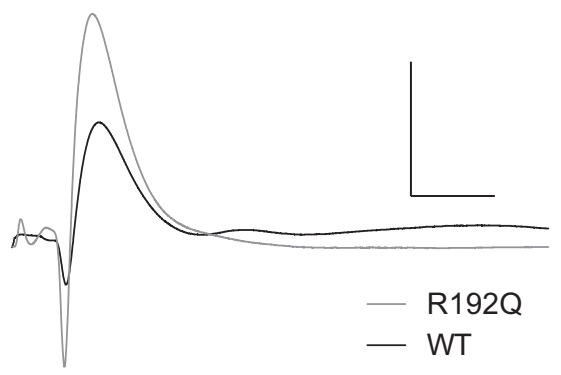

C

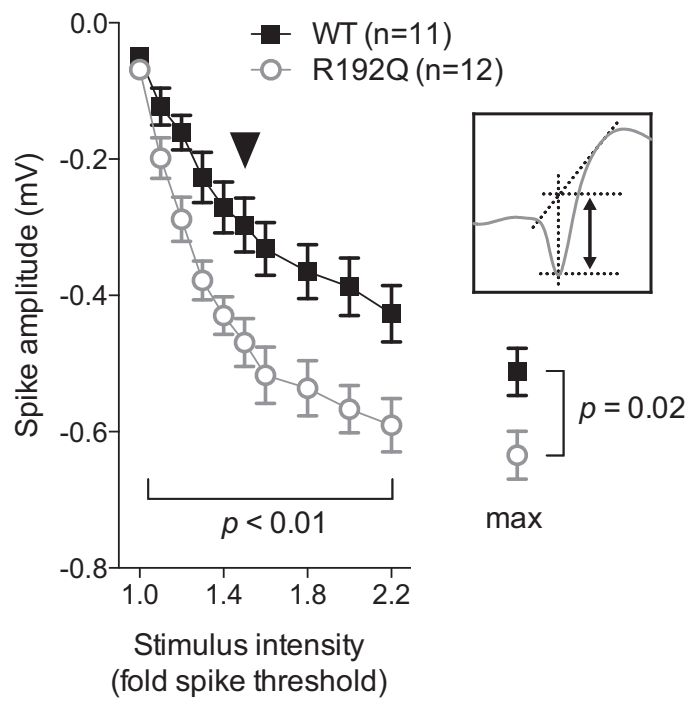

B Stratum radiatum

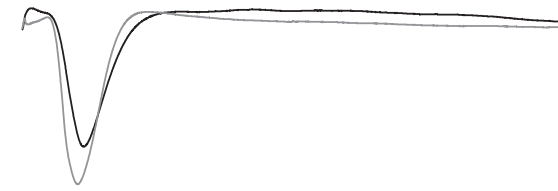

D

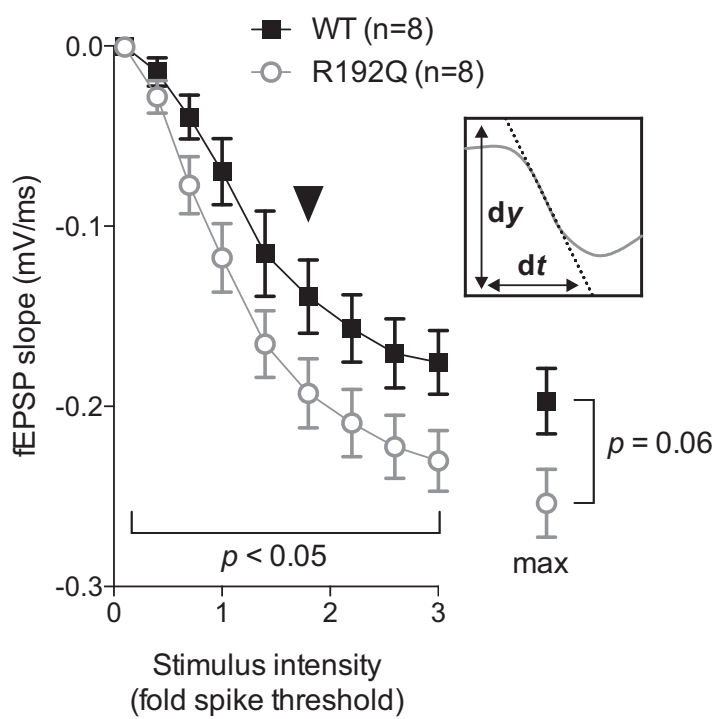

Figure 1. Hippocampal evoked field potentials. Representative responses ( $\boldsymbol{A}$, stratum pyramidale; $\boldsymbol{B}$, stratum radiatum; calibration: $0.5 \mathrm{mV}$, $10 \mathrm{~ms}$ ) and averaged data show spike amplitude versus stimulus intensity in the stratum pyramidale $(\boldsymbol{C})$ and fEPSP slope in the stratum radiatum $(\boldsymbol{D})$ in WT and R1920 mice. Insets show how spike amplitude $(\boldsymbol{C})$ and fEPSP slope $(\boldsymbol{D})$ were measured. Maximum responses are shown on the right of each curve, obtained at stimulus intensities of 3.7 \pm 0.4 - and 3.1 \pm 0.3 -fold spike threshold in stratum pyramidale $(\boldsymbol{C})$ and of 3.9 \pm 0.6 - and $4.0 \pm$ 0.3 -fold spike threshold in stratum radiatum $(\boldsymbol{D})$, in WT and R192Q, respectively $(p>0.05)$. Arrowheads in $\boldsymbol{C}$ and $\boldsymbol{D}$ indicate stimulus intensities at which sample tracings in $\boldsymbol{A}$ and $\boldsymbol{B}$ were 0 btained. C, The spike amplitude was decreased more in R192Q mutants compared with control (two-way repeated-measures ANOVA, interaction factors stimulus intensity $\times$ genotype, $F_{(9,189)}=3.202, p<$ 0.01). D, Mutants also showed decreased fEPSP slopes after increased stimulus intensity (two-way repeated-measures ANOVA, interaction factors stimulus intensity $\times$ genotype, $F_{(8,120)}=2.103$, $p<0.05)$. Maximum responses were analyzed using a Student's $t$ test. Data are mean \pm SE.

steeper, and maximal fEPSP slopes were larger in R192Q mice compared with WT controls (Fig. $1 D$ ), presumably reflecting enhanced presynaptic excitatory neurotransmitter release.

High-frequency stimulus trains to induce LTP significantly increased fEPSP slopes in both WT and homozygous R192Q mice (two-way repeated measures ANOVA, factor time, $\left.F_{(167,2338)}=3.246, p<0.01\right)$, which persisted for at least $60 \mathrm{~min}$ (Fig. $2 A, C$ ). LTP magnitude was significantly larger in the FHM1 mutant. Low-frequency paired pulses induced lasting long-term depression (LTD) of fEPSP slopes in both groups (Fig. $2 B, D$; two-way repeated measures ANOVA, factor time, $F_{(193,2316)}=$ $14.24, p<0.01)$. In contrast to LTP, LTD magnitude was identical in WT and homozygous R192Q mice.

\section{Behavioral testing}

We examined WT and FHM1 mice using two learning and memory paradigms that critically depend on hippocampal function [fear conditioning (Matus-Amat et al., 2004), water maze (Morris et al., 1982)] and a third paradigm believed to rely on distrib- uted connections among multiple brain regions (novel object recognition; Moses et al., 2005).

In the contextual fear-conditioning test, mice learn to associate a distinctive context with the unconditioned aversive stimulus, and retrieval of context memory is assessed $24 \mathrm{~h}$ later (Fig. $3 A$ ). Basal freezing time did not differ between WT and mutant strains before shock exposure (Fig. $3 B$ ). Twenty-four hours later, R192Q mice showed significantly shorter contextual freezing (Fig. 3B; Mann-Whitney $U$ test, genotype, $p<0.01$ ), indicating impaired contextual hippocampal learning. Importantly, the $V_{\max }$ response to the $2 \mathrm{~s}, 0.7 \mathrm{~mA}$ shock did not differ between groups, suggesting that mice from both genotypes perceived the shock similarly (Fig. 3C).

In the Morris water maze, the time to reach the hidden platform was equal between WT and homozygous R192Q mice during the first training session (Fig. $3 D$, trial 1) and gradually became shorter after repeated sessions in both groups (two-way repeated-measures ANOVA, factor time, $F_{(4,32)}=7.657, p<$ $0.01)$. However, the rate of decrease in time to reach the hidden 
A

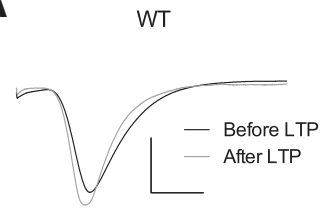

$\mathrm{R} 192 \mathrm{Q}$

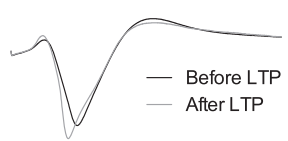

B
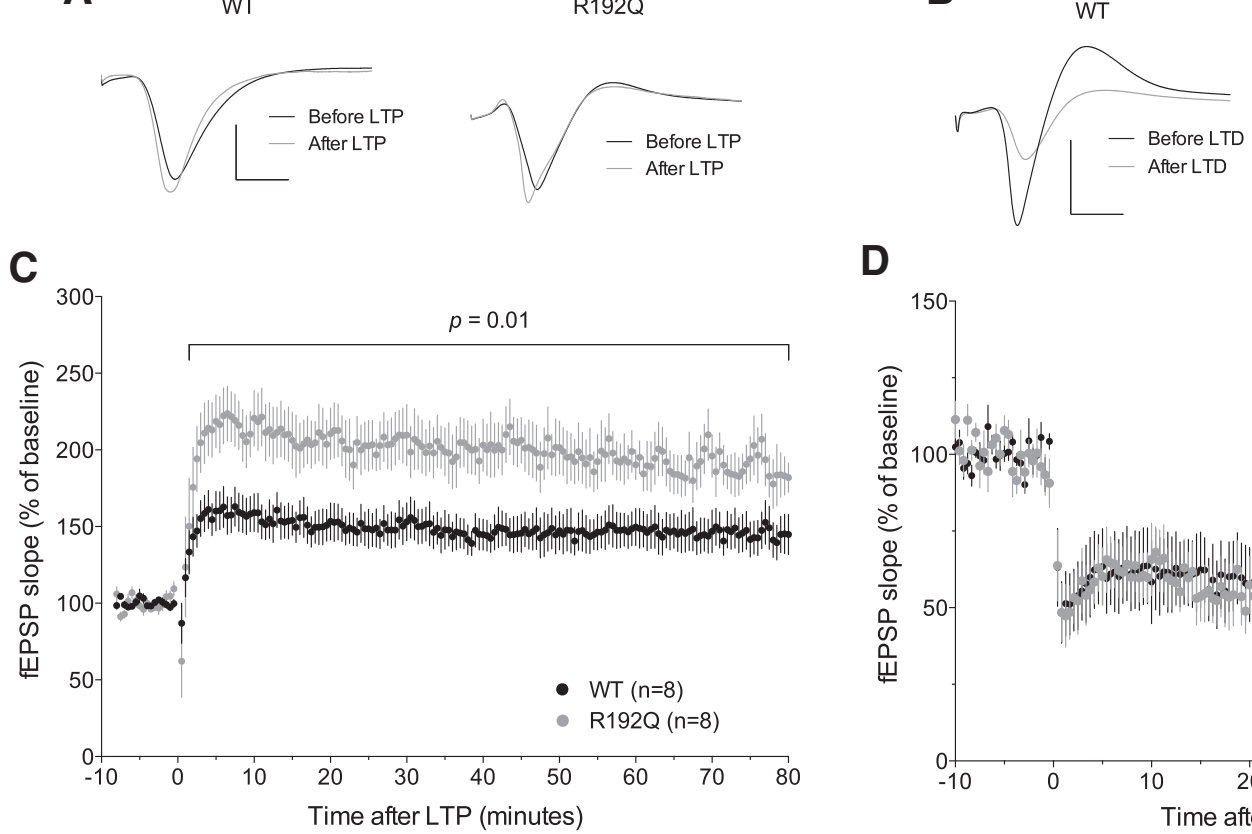

D

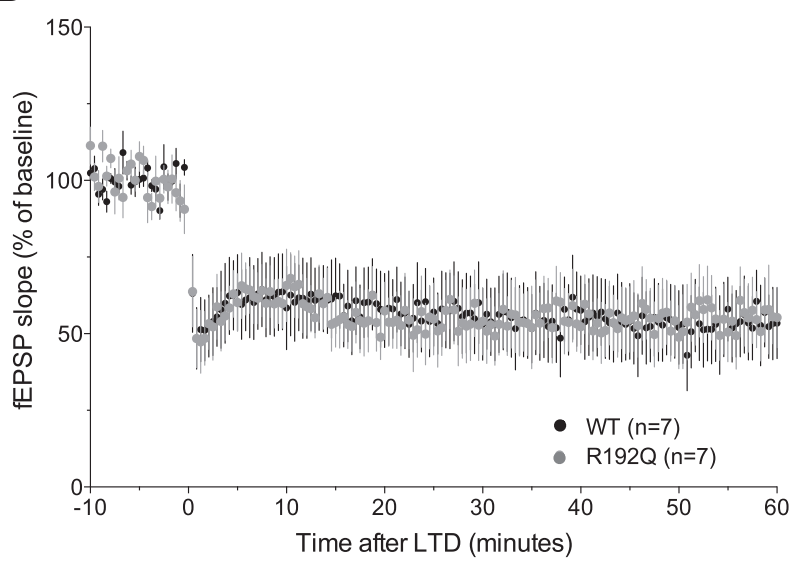

Figure 2. Long-term potentiation and depression in stratum radiatum. A, Representative sweeps show fEPSPs before and after tetanic stimulation to induce LTP (calibration: $0.3 \mathrm{mV}, 5 \mathrm{~ms}$ ). $C$, After high-frequency stimulation (time 0 ), the fEPSP slope increased by 1.5-fold of baseline in WT mice and by more than twofold in R1920 mutants (two-way repeated-measures ANOVA starting at 1 min after stimulation, factor genotype, $F_{(1,14)}=7.788, p=0.01$ ). $\boldsymbol{B}$, Representative sweeps show fEPSPs before and after low-frequency paired-pulse stimulation to induce LTD (calibration: $0.2 \mathrm{mV}, 5 \mathrm{~ms}$ ). $\boldsymbol{D}$, After low-frequency paired-pulse stimulation (time 0 ), the fEPSP slope decreased to $\sim 50 \%$ of baseline in both WT and R1920 knock-in mice (two-way repeated-measures ANOVA starting at 1 min after stimulation, factor genotype, $\left.F_{(1,12)}=0.001, p=0.98\right)$. Data are mean $\pm \mathrm{SE}$.

A

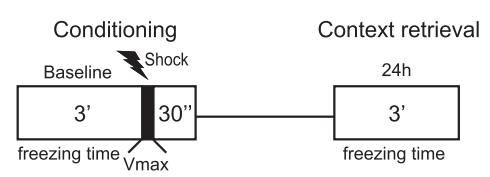

B

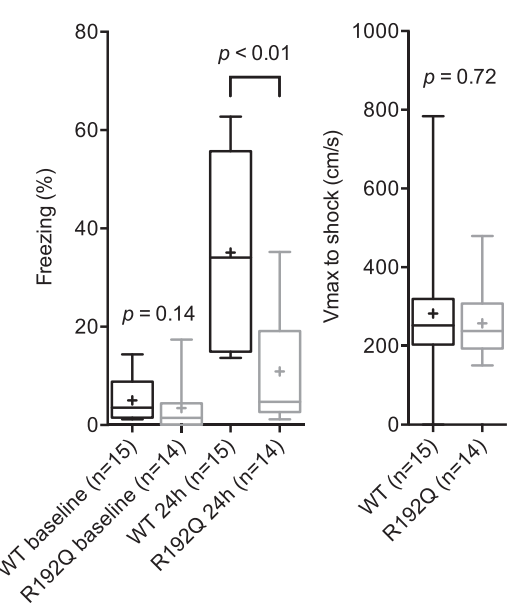

D

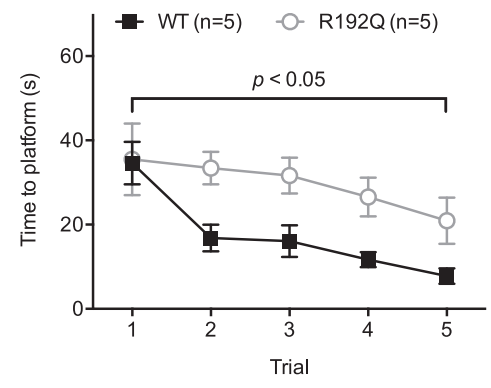

E

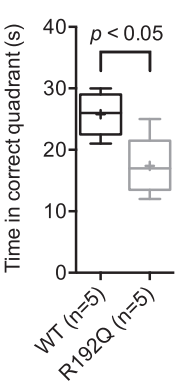

G

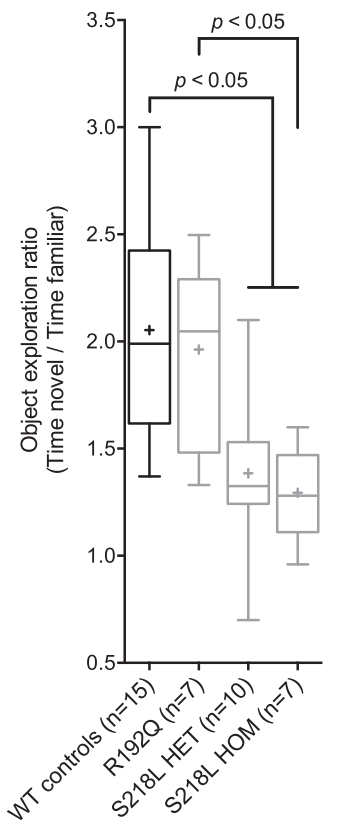

Figure 3. Learning and memory tests. $A-C$, Fear-conditioning test. $A$, Experimental design for contextual fear conditioning, in which mice were exposed to the context in which they received a $\operatorname{shock}(2 \mathrm{~s}, 0.7 \mathrm{~mA})$ after $3 \mathrm{~min}$ (conditioning) and were re-exposed to the context $24 \mathrm{~h}$ later. Readouts include the freezing time and $V_{\max }$, , Freezing response (percentage of total time spent in cage) in WT and homozygous R1920 knock-in mice at baseline and $24 \mathrm{~h}$ later showed a genotype effect for retrieval (Mann-Whitney $U$ tests). C, Both groups had a similar reaction to the shock (maximal velocity; $V_{\text {max }} ;$ Mann-Whitney $U$ test), ruling out hypersensitivity or hyposensitivity as a confounder. $D$, Morris water maze learning curve. FHM1 mice needed more time to reach the hidden platform throughout the $5 \mathrm{~d}$ testing period, suggesting impaired spatial hippocampal learning (two-way repeated-measures ANOVA, factor genotype, $\left.F_{(1,8)}=8.434, p<0.05\right)$. $E$, Morris water maze probe test. After removal of the platform at the end of training, R192Q mice spent significantly less time in the quadrant where the platform was located (Mann-Whitney U test). $\boldsymbol{F}$, Visible platform test. R192Q mice reached the visible platform at the same time as WT mice (Mann-Whitney U test). G, Novel object recognition. The ratio of time spent exploring a novel object versus a familiar object was comparable in R1920 mice and WT mice but lower in heterozygous and homozygous $\$ 218 \mathrm{~L}$ compared with WT mice. Homozygous $5218 \mathrm{~L}$ mice also performed significantly worse than R1920 mice (Kruskal-Wallistest followed by the Dunn's multiple comparisons test). Whisker-box plots show median (horizontal line), mean (+), 25-75\% range (box), and full range (whisker). The line graph shows mean \pm SE. 
platform was significantly slower in R192Q mice compared with WT mice, again suggesting impaired spatial learning in FHM1 mice (Fig. 3D). Indeed, when mice were reintroduced in the water maze in the absence of the platform (i.e., probe test), R192Q mice spent significantly less time in the quadrant where the platform used to be (Fig. $3 E$ ). Both groups reached the visible platform at the same time (Fig. $3 F$ ), suggesting that visual and motor function were comparable between the groups.

In the novel object recognition test, the time spent exploring a novel object compared with a familiar object was similar between WT and R192Q mice. In contrast, both heterozygous and homozygous S218L mice performed significantly worse than the WT mice (Fig. 3G; Kruskal-Wallis test followed by Dunn's multiple comparisons test, $p<0.01$ ), and homozygous S218L performed significantly worse than R192Q mice (Kruskal-Wallis test followed by Dunn's multiple comparisons test, $p<0.05$ ).

\section{Discussion}

Our data show for the first time hippocampal network hyperexcitability and its cognitive consequences in a mouse model of FHM1 in vivo. Monosynaptic hippocampal CA1 fEPSP slopes were steeper in the stratum radiatum and population spikes larger in the stratum pyramidale, suggesting enhanced glutamatergic neurotransmission and synchronous action potential firing in response to an afferent fiber volley. The LTP of evoked field potentials was significantly stronger in the FHM1 transgenic mice, without a change in LTD. Paradoxically, however, learning and memory in FHM1 mutants was impaired. Memory dysfunction involved paradigms critically dependent on hippocampal function, as well as one that relies on distributed involvement of multiple brain regions, consistent with the complex clinical phenotype.

In most studies, learning and memory changes in the same direction with LTP. The majority of animal models with enhanced LTP shows enhanced learning and memory (Lee and Silva, 2009; Wang et al., 2009; Han et al., 2013), and vice versa (Lu et al., 1997; Saxe et al., 2006). However, exceptions exist where an inverse relationship between LTP and learning and memory was observed (Jolas et al., 2002; D'Hooge et al., 2005; Müller et al., 2013), resembling our findings in FHM1 mutants. Impaired learning and memory in the presence of overly enhanced LTP is not necessarily counterintuitive (Taverna et al., 2005). Proper encoding and consolidation of memory, as well as memory recall and subsequent reconsolidation (Rao-Ruiz et al., 2011), likely requires just the right amount of plasticity. Metaphorically, a completely white page is as uninformative as a completely black page. Too much plasticity would strengthen and perhaps saturate all synapses and be as detrimental to acquisition and recall of memory as is too little plasticity.

It should be noted, however, that although the explanation above is highly plausible, we have not directly recorded hippocampal plasticity during learning tasks and therefore cannot fully substantiate a causal link between enhanced LTP and impaired learning in the mutants. For example, FHM1 mice may develop spontaneous spreading depressions that, if frequent enough, can lead to impaired memory acquisition and recall, much like that observed in transient global amnesia (Olesen and Jørgensen, 1986; Strupp et al., 1998). As such, enhanced LTP may not be causally related to impaired memory.

Interestingly, LTD, which also depends on glutamatergic neurotransmission (Collingridge et al., 2010), was not augmented in FHM1 mice. In contrast to LTP, however, hippocampal LTD propensity varies depending on the experimental paradigm (Goh and Manahan-Vaughan, 2013; Gonzalez et al., 2014), suggesting the possibility that in a different LTD paradigm, FHM1 mutations may augment LTD. Nevertheless, one could speculate that, should there be enhanced LTD, it might have balanced the enhanced LTP and ameliorated the memory deficits. As such, the combination of enhanced LTP with unchanged LTD may be critical for impaired memory.

The novel object recognition test revealed a critical genotypephenotype relationship in FHM1 mutants. In contrast to the hippocampus-dependent fear-conditioning and water maze tests, the R192Q mice showed normal novel object recognition, which relies on a more distributed network of brain structures (Antunes and Biala, 2012). Only the S218L mutants showed significant deficits in the latter test. It is well established that the R192Q mutation causes weaker $\mathrm{Ca}_{\mathrm{V}} 2.1$ gain-of-function and a milder (i.e., pure) FHM phenotype than the S218L mutation, both in patients (Kors et al., 2001; Stam et al., 2009) and in transgenic mice (van den Maagdenberg et al., 2004, 2010; EikermannHaerter et al., 2009). This genotype-phenotype relationship suggests that hippocampal learning and memory is more sensitive to the disruptive effects of FHM1 mutations, whereas an impairment in more distributed learning and memory may require more pronounced changes in glutamatergic neurotransmission caused by the S218L mutation (van den Maagdenberg et al., 2010; Pietrobon, 2013). This is reminiscent of the overt ataxia phenotype associated with the S218L but not the R192Q mutation in patients and transgenic mice (Stam et al., 2009; van den Maagdenberg et al., 2010).

In summary, the data suggest that a genetic predisposition for enhanced synaptic transmission and spreading depression susceptibility may impact cognitive performance, despite compensatory mechanisms trying to harness the glutamatergic transmission, such as upregulation of glutamate transporters (Klychnikov et al., 2010).

\section{References}

Antunes M, Biala G (2012) The novel object recognition memory: neurobiology, test procedure, and its modifications. Cogn Process 13:93-110. CrossRef Medline

Bohbot VD, Kalina M, Stepankova K, Spackova N, Petrides M, Nadel L (1998) Spatial memory deficits in patients with lesions to the right hippocampus and to the right parahippocampal cortex. Neuropsychologia 36:1217-1238. CrossRef Medline

Calandre EP, Bembibre J, Arnedo ML, Becerra D (2002) Cognitive disturbances and regional cerebral blood flow abnormalities in migraine patients: their relationship with the clinical manifestations of the illness. Cephalalgia 22:291-302. CrossRef Medline

Collingridge GL, Peineau S, Howland JG, Wang YT (2010) Long-term depression in the CNS. Nat Rev Neurosci 11:459-473. CrossRef Medline

D’Hooge R, Lüllmann-Rauch R, Beckers T, Balschun D, Schwake M, Reiss K, von Figura K, Saftig P (2005) Neurocognitive and psychotiform behavioral alterations and enhanced hippocampal long-term potentiation in transgenic mice displaying neuropathological features of human alphamannosidosis. J Neurosci 25:6539-6549. CrossRef Medline

Eikermann-Haerter K, Dileköz E, Kudo C, Savitz SI, Waeber C, Baum MJ, Ferrari MD, van den Maagdenberg AM, Moskowitz MA, Ayata C (2009) Genetic and hormonal factors modulate spreading depression and transient hemiparesis in mouse models of familial hemiplegic migraine type 1 . J Clin Invest 119:99-109. CrossRef Medline

Eikermann-Haerter K, Yuzawa I, Qin T, Wang Y, Baek K, Kim YR, Hoffmann U, Dileköz E, Waeber C, Ferrari MD, van den Maagdenberg AM, Moskowitz MA, Ayata C (2011) Enhanced subcortical spreading depression in familial hemiplegic migraine type 1 mutant mice. J Neurosci 31:57555763. CrossRef Medline

Freilinger T, Ackl N, Ebert A, Schmidt C, Rautenstrauss B, Dichgans M, Danek A (2011) A novel mutation in CACNA1A associated with hemi- 
plegic migraine, cerebellar dysfunction and late-onset cognitive decline. J Neurol Sci 300:160-163. CrossRef Medline

Goh JJ, Manahan-Vaughan D (2013) Synaptic depression in the CA1 region of freely behaving mice is highly dependent on afferent stimulation parameters. Front Integr Neurosci 7:1-13. CrossRef Medline

Gonzalez J, Morales IS, Villarreal DM, Derrick BE (2014) Low-frequency stimulation induces long-term depression and slow onset long-term potentiation at perforant path-dentate gyrus synapses in vivo. J Neurophysiol 111:1259-1273. CrossRef Medline

Han X, Chen M, Wang F, Windrem M, Wang S, Shanz S, Xu Q, Oberheim NA, Bekar L, Betstadt S, Silva AJ, Takano T, Goldman SA, Nedergaard M (2013) Forebrain engraftment by human glial progenitor cells enhances synaptic plasticity and learning in adult mice. Cell Stem Cell 12:342-353. CrossRef Medline

Headache Classification Subcommittee of the International Headache Society (2004) The International Classification of Headache Disorders: 2nd edition. Cephalalgia 24 [Suppl 1]:9-160.

Jolas T, Zhang XS, Zhang Q, Wong G, Del Vecchio R, Gold L, Priestley T (2002) Long-term potentiation is increased in the CAl area of the hippocampus of $\mathrm{APP}_{\text {swe/ind }}$ CRND8 mice. Neurobiol Dis 11:394-409. CrossRef Medline

Kalaydjian A, Zandi PP, Swartz KL, Eaton WW, Lyketsos C (2007) How migraines impact cognitive function: findings from the Baltimore ECA. Neurology 68:1417-1424. CrossRef Medline

Karner E, Delazer M, Benke T, Bösch S (2010) Cognitive functions, emotional behavior, and quality of life in familial hemiplegic migraine. Cogn Behav Neurol 23:106-111. CrossRef Medline

Karner E, Nachbauer W, Bodner T, Benke T, Boesch S, Delazer M (2012) Long-term outcome of cognitive functions, emotional behavior, and quality of life in a family with familial hemiplegic migraine. Cogn Behav Neurol 25:85-92. CrossRef Medline

Klychnikov OI, Li KW, Sidorov IA, Loos M, Spijker S, Broos LA, Frants RR, Ferrari MD, Mayboroda OA, Deelder AM, Smit AB, van den Maagdenberg AM (2010) Quantitative cortical synapse proteomics of a transgenic migraine mouse model with mutated $\mathrm{Ca}(\mathrm{V}) 2.1$ calcium channels. Proteomics 10:2531-2535. CrossRef Medline

Kors EE, Terwindt GM, Vermeulen FL, Fitzsimons RB, Jardine PE, Heywood P, Love S, van den Maagdenberg AM, Haan J, Frants RR, Ferrari MD (2001) Delayed cerebral edema and fatal coma after minor head trauma: role of the CACNA1A calcium channel subunit gene and relationship with familial hemiplegic migraine. Ann Neurol 49:753-760. CrossRef Medline

Kors EE, Haan J, Giffin NJ, Pazdera L, Schnittger C, Lennox GG, Terwindt GM, Vermeulen FL, van den Maagdenberg AM, Frants RR, Ferrari MD (2003) Expanding the phenotypic spectrum of the CACNA1A gene T666M mutation: a description of 5 families with familial hemiplegic migraine. Arch Neurol 60:684-688. CrossRef Medline

Lee YS, Silva AJ (2009) The molecular and cellular biology of enhanced cognition. Nat Rev Neurosci 10:126-140. CrossRef Medline

Le Pira F, Zappalà G, Giuffrida S, Lo Bartolo ML, Reggio E, Morana R, Lanaia F (2000) Memory disturbances in migraine with and without aura: a strategy problem? Cephalalgia 20:475-478. CrossRef Medline

Lu YM, Jia Z, Janus C, Henderson JT, Gerlai R, Wojtowicz JM, Roder JC (1997) Mice lacking metabotropic glutamate receptor 5 show impaired learning and reduced CA1 long-term potentiation (LTP) but normal CA3 LTP. J Neurosci 17:5196-5205. Medline

Matus-Amat P, Higgins EA, Barrientos RM, Rudy JW (2004) The role of the dorsal hippocampus in the acquisition and retrieval of context memory representations. J Neurosci 24:2431-2439. CrossRef Medline

Morris RG, Garrud P, Rawlins JN, O'Keefe J (1982) Place navigation impaired in rats with hippocampal lesions. Nature 297:681-683. CrossRef Medline

Moses SN, Cole C, Driscoll I, Ryan JD (2005) Differential contributions of hippocampus, amygdala and perirhinal cortex to recognition of novel objects, contextual stimuli and stimulus relationships. Brain Res Bull 67: 62-76. CrossRef Medline
Müller L, Tokay T, Porath K, Köhling R, Kirschstein T (2013) Enhanced NMDA receptor-dependent LTP in the epileptic CA1 area via upregulation of NR2B. Neurobiol Dis 54:183-193. CrossRef Medline

Olesen J, Jørgensen MB (1986) Leao's spreading depression in the hippocampus explains transient global amnesia. A hypothesis. Acta Neurol Scand 73:219-220. Medline

Ophoff RA, Terwindt GM, Vergouwe MN, van Eijk R, Oefner PJ, Hoffman SM, Lamerdin JE, Mohrenweiser HW, Bulman DE, Ferrari M, Haan J, Lindhout D, van Ommen GJ, Hofker MH, Ferrari MD, Frants RR (1996) Familial hemiplegic migraine and episodic ataxia type- 2 are caused by mutations in the $\mathrm{Ca} 2+$ channel gene CACNL1A4. Cell 87:543-552. CrossRef Medline

Pietrobon D (2013) Calcium channels and migraine. Biochim Biophys Acta 1828:1655-1665. CrossRef Medline

Pietrobon D, Moskowitz MA (2013) Pathophysiology of migraine. Annu Rev Physiol 75:365-391. CrossRef Medline

Rao-Ruiz P, Rotaru DC, van der Loo RJ, Mansvelder HD, Stiedl O, Smit AB, Spijker S (2011) Retrieval-specific endocytosis of GluA2-AMPARs underlies adaptive reconsolidation of contextual fear. Nat Neurosci 14: 1302-1308. CrossRef Medline

Saxe MD, Battaglia F, Wang JW, Malleret G, David DJ, Monckton JE, Garcia AD, Sofroniew MV, Kandel ER, Santarelli L, Hen R, Drew MR (2006) Ablation of hippocampal neurogenesis impairs contextual fear conditioning and synaptic plasticity in the dentate gyrus. Proc Natl Acad Sci U S A 103:17501-17506. CrossRef Medline

Stam AH, Luijckx GJ, Poll-Thé BT, Ginjaar IB, Frants RR, Haan J, Ferrari MD, Terwindt GM, van den Maagdenberg AM (2009) Early seizures and cerebral oedema after trivial head trauma associated with the CACNA1A S218L mutation. J Neurol Neurosurg Psychiatr 80:1125-1129. CrossRef Medline

Strupp M, Brüning R, Wu RH, Deimling M, Reiser M, Brandt T (1998) Diffusion-weighted MRI in transient global amnesia: elevated signal intensity in the left mesial temporal lobe in 7 of 10 patients. Ann Neurol 43:164-170. CrossRef Medline

Suhr JA, Seng EK (2012) Neuropsychological functioning in migraine: clinical and research implications. Cephalalgia 32:39-54. CrossRef Medline

Taverna FA, Georgiou J, McDonald RJ, Hong NS, Kraev A, Salter MW, Takeshima H, Muller RU, Roder JC (2005) Defective place cell activity in nociceptin receptor knockout mice with elevated NMDA receptordependent long-term potentiation. J Physiol 565:579-591. CrossRef Medline

Tottene A, Fellin T, Pagnutti S, Luvisetto S, Striessnig J, Fletcher C, Pietrobon D (2002) Familial hemiplegic migraine mutations increase $\mathrm{Ca}(2+)$ influx through single human CaV2.1 channels and decrease maximal CaV2.1 current density in neurons. Proc Natl Acad Sci U S A 99:1328413289. CrossRef Medline

Tottene A, Conti R, Fabbro A, Vecchia D, Shapovalova M, Santello M, van den Maagdenberg AM, Ferrari MD, Pietrobon D (2009) Enhanced excitatory transmission at cortical synapses as the basis for facilitated spreading depression in $\mathrm{Ca}(\mathrm{v}) 2.1$ knockin migraine mice. Neuron 61: 762-773. CrossRef Medline

van den Maagdenberg AM, Pietrobon D, Pizzorusso T, Kaja S, Broos LA, Cesetti T, van de Ven RC, Tottene A, van der Kaa J, Plomp JJ, Frants RR, Ferrari MD (2004) A Cacnala knockin migraine mouse model with increased susceptibility to cortical spreading depression. Neuron 41:701710. CrossRef Medline

van den Maagdenberg AM, Pizzorusso T, Kaja S, Terpolilli N, Shapovalova M, Hoebeek FE, Barrett CF, Gherardini L, van de Ven RC, Todorov B, Broos LA, Tottene A, Gao Z, Fodor M, De Zeeuw CI, Frants RR, Plesnila N, Plomp JJ, Pietrobon D, Ferrari MD (2010) High cortical spreading depression susceptibility and migraine-associated symptoms in $\mathrm{Ca}(\mathrm{v}) 2.1$ S218L mice. Ann Neurol 67:85-98. CrossRef Medline

Wang D, Cui Z, Zeng Q, Kuang H, Wang LP, Tsien JZ, Cao X (2009) Genetic enhancement of memory and long-term potentiation but not CA1 longterm depression in NR2B transgenic rats. PLoS One 4:e7486. CrossRef Medline 